\title{
RUNOFF MODELING FOR MALAPRABHA SUB-BASIN USING SWAT HYDROLOGICAL MODEL
}

\author{
Priyanka $^{1}$, Nagraj S. Patil ${ }^{2}$ \\ ${ }^{I}$ Final year M. Tech, Department of Water and Land Management, Center for PG Studies, VTU, Belagavi, Karnataka, \\ India \\ ${ }^{2}$ Associate Professor Department of Water and Land Management, Center for PG Studies, VTU, Belagavi, Karnataka, \\ India
}

\begin{abstract}
Water being one of the very important natural resources whose management has become the ultimate challenge facing today. As the population is growing impulsively, the demand for water is also increasing intensively. Demanding urbanization and the expansion of industries and development in agricultural practices also add up to the increasing demand for water. It is very much essential to manage the resource and use it wisely. With this perspective, hydrological modeling plays a vital role which can act as an important tool for the assessment of water functioning at the basin scale. In the present study, the Soil and Water Assessment Tool (SWAT), a mathematical model which aims at improving land and water quality supporting land use planning with greater potential is interfaced with ArcGIS software has been used to estimate runoff for Malaprabha sub-basin. The model is calibrated and validated using observed runoff. Calibration is done manually. The model was calibrated and validated using observed runoff for the period 1982-1989. The model was calibrated for the period 1982-1985 and validated for the period 19861989. By this study we come to know that SWAT can be used to simulate runoff process in Malaprabha Sub-basin. The study found that the observed values showed good agreement with the simulated Flow with corresponding optimal set of parameters.
\end{abstract}

Keywords: Hydrological model, Runoff, SWAT model, Malaprabha Sub-basin

\section{INTRODUCTION}

It is recognized by The National Water Policy of India (2002) that it is very essential to manage the water resources in order to improve and preserve the limited resource water in an incorporated way [1]. The runoff estimation is useful for the assessment of floods, reservoir maneuver and transport of contaminated water [1]. Runoff modeling is necessary for viable growth for enumerating the hydrological parameters [2].

Runoff estimation becomes difficult and much time taking process by conventional techniques especially for isolated and unapproachable areas [3]. Hence it is the present days fashion to use mathematical models for hydrological assessment of watershed limits done utilizing the remotely sensed data by use of Geographical Information System (GIS) which have become the supporting techniques [3].

SWAT model was developed by the USDA Agricultural Research Service (ARS), to assess the impacts of land use practices on sediment yield, water quality and chemical yields over long period of time in vast watersheds having different kinds of soils and land use practices. The model requires precise information on properties of soil, vegetation, weather, topography and management practices of land taking place in the watershed [4][5]. SWAT uses the Soil Conservation Service Curve Number (CN) for estimation of runoff, which associates runoff response to soils, land use, and rainfall [6].

\section{STUDY AREA}

In India, Krishna river basin is one of the largest basin. The basin lies in the Deccan Plateau. The Malaprabha, the Ghataprabha, the Tungabhadra, the Bhima and Musi are the main tributaries of Krishna basin. The catchment area of Malaprabha lies amid $15^{\circ} 00^{\prime} \mathrm{N}$ and $16^{\circ} 12^{\prime} \mathrm{N}$ and $74^{\circ} 14^{\prime} \mathrm{E}$ and $76^{\circ} 05^{\prime}$ E. From Chorla Ghats which is a Western Ghats segment, the Malaprabha River starts. The river joins Krishna at KapilaSangam at an altitude of around $488 \mathrm{~m}$ streaming east and north-west. Malaprabha meets the Krishna River after it crosses a length of $306 \mathrm{~km}$ covering catchment area of 11,549 sq. $\mathrm{km}$.

The river joins the Krishna River after flowing for a distance of $304 \mathrm{~km}$ near Kudal Sangam in Bagalkot District of State Karnataka at an elevation of 488 meters. It additionally progresses through Dharwad District. Hubli city gets the drinking water from this reservoir. The Navilateertha Dam is built nearby Munavalli in Belgaum District with a capacity limit of $1.07 \mathrm{~km}^{3}$. This reservoir is called Renukasagar which irrigates more than 2,000 square kilometers of area.

The stream from this basin is declining because of reduced precipitation throughout the years furthermore because of upstream improvement in catchment region. The constant stream is around 75 percent around 1,857 MCM. Additionally this basin serves for horticultural requests. The Malaprabha supply was alleged in 1974 and has a gross storing limit of $1070 \mathrm{MCM}$ and a live storing limit of 830 MCM. 
Two main geological formations are found in the basin (i) Tertiary basalts, (ii) Sedimentary formations. Red soils cover the $80 \%$ area of the Malaprabha basin. Black soils are found extensively in parts of Khanapur taluk. About $16.85 \%$ of the area falls under agricultural land. Cereals like paddy, ragi, etc. and cash crops such as sugarcane and cotton are the chief crops grown. The study area location has been demonstrated in below Fig. 1 .

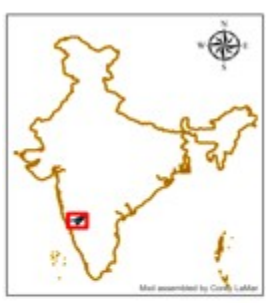

\section{STUDY AREA}

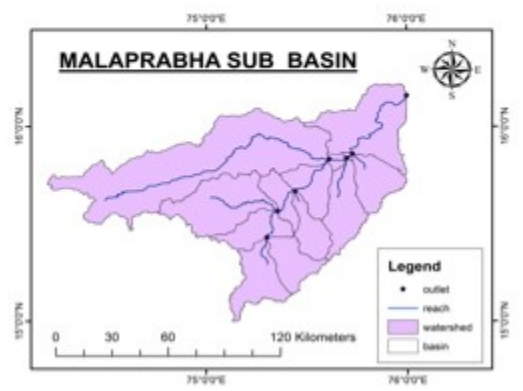

Fig-1: Study area location

\section{METHOCOLOGY}

\subsection{Hydrological Modeling}

Hydrological models are the simplified mathematical demonstrations of a real hydrological system such as a river basin or a part of it. The main tools for hydrologist are the hydrological models used for different purposes such as water resource management, modeling of groundwater, watershed management for both urban and rural watersheds etc. Hydrological models have been classified differently aiming to make the models easily understandable and can be operated easily.

Generally, based on the mathematical structures, hydrological models are described by using different terms from three basic categories, viz., simulation basis, spatial representation and temporal representation. Again these can be subdivided into subcategories. Simulation basis comprises of empirical or regression, theoretical, physically based and stochastic time series. Lumped, distributed and semi distributed systems are included in Spatial representation category. Single-event and continuous representations are comprised under the temporal representation category.

\subsection{SWAT Model}

Hydrological model SWAT is the widely used for sedimentation yield studies. These models require Digital Elevation Model (DEM), Land Use/ Land Cover (LULC) map, soil map and meteorological data etc. of the catchment area. SWAT has the efficiency to be directly modeled for the physical processes such as sediment transport, nutrient cycling, crop growth etc. by using the above stated informations.
Water balance equation is used by the SWAT model behind all the processes. Since the equation influences plant growth and the movement of sediments, pesticides, pathogens, and nutrients [4]. The equation is shown as below:

$$
S W_{t}=S W_{o} \sum_{i=1}^{t}\left(R_{\text {day }}-Q_{\text {surf }}-E_{a}-W_{\text {seep }}-Q_{g w}\right)
$$

Where,

$S W_{t}$-final soil water content

$S W_{o}$-initial soil water content

t-time in days

$R_{\text {day }}$-amount of precipitation on day $\mathrm{i}$

$Q_{\text {surf }}$-amount of surface runoff on day i

$E_{a}$-amount of evapotranspiration on day i

$W_{\text {seep }}$-amount of percolation and bypass flow exiting the soil profile bottom on day $\mathrm{i}$

$Q_{g w}$-amount of return flow on day i

Model set up and execution is done following the flow chart as shown in fig. 2 below.

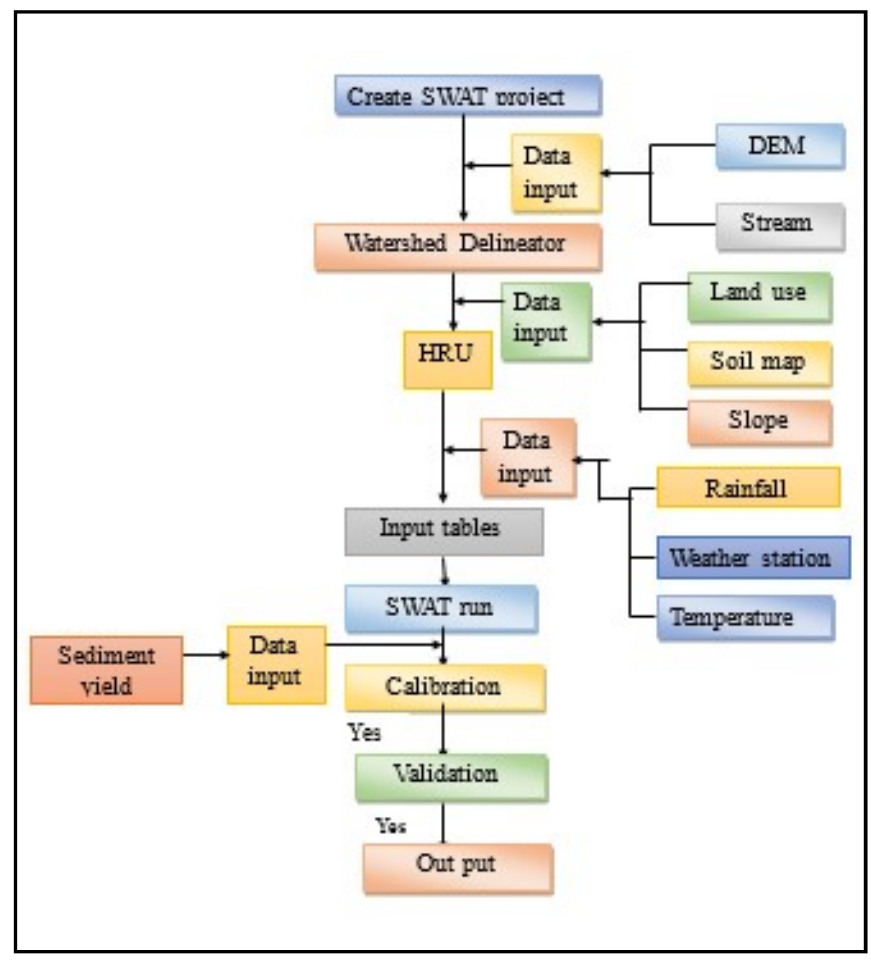

Fig. 2: Flowchart for SWAT methodology

\subsection{Data Required}

- $\quad$ DEM (Fig.3)

- Topographic map

- $\quad$ Soil classes

- $\quad$ LULC map (Fig.4)

- Weather data 


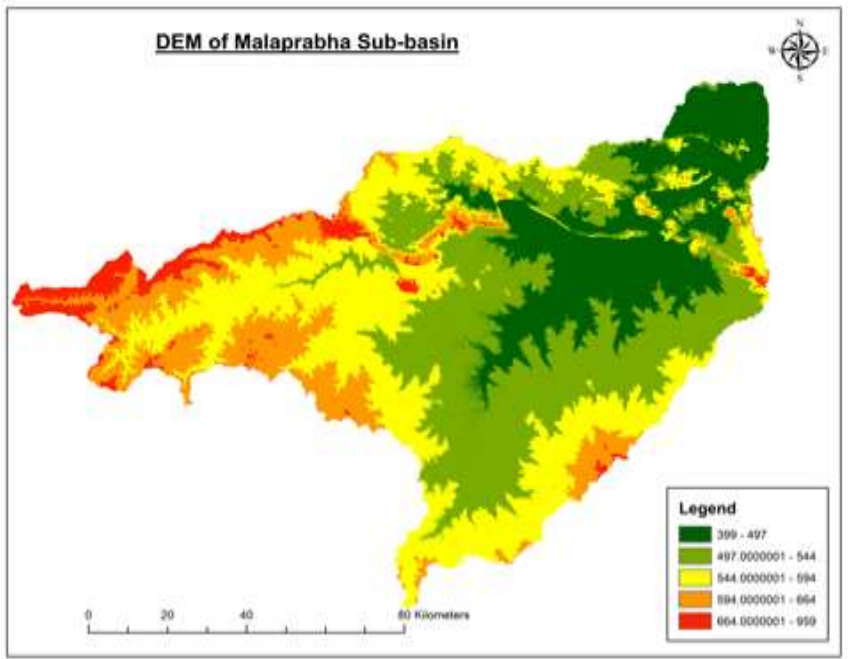

Fig. 3: DEM of Malaprabha Sub-basin

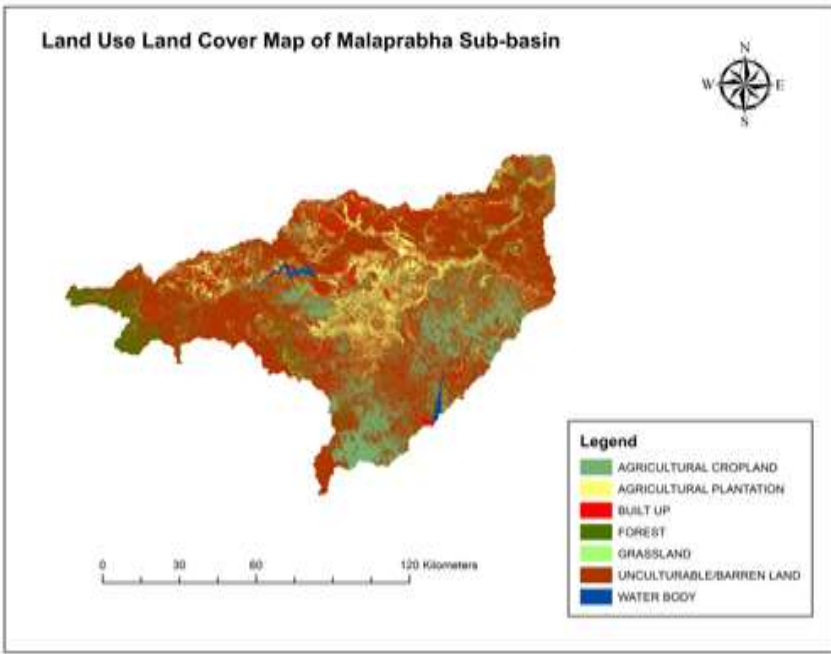

Fig. 4: LULC of Malaprabha Sub-basin

\section{RESULTS AND DISCUSSIONS}

The sensitive parameters based on the literature survey (Arnold 2001; Santhi et al. 2001; van Griensven et al. 2006) and SWAT documentation (Neitschet al.2002)have been chosen for model calibration.

Calibration is the progression of altering sensitive parameters so as to reduce the difference between observed and simulated runoff response [6]. Validation is the comparison of model outputs with, for different time series without any further adjustments of the values of the parameters that was calibrated and it is done to confirm that the model performs satisfactorily.

The calibration was done for the period 1981 to 1985 and was validated from 1986 to 1989 . Initially, before calibration, the observed values and simulated peak values weren't matching with each other as shown in fig. $5 . \mathrm{R}^{2}$ and NSE values were found to be 0.5759 and 0.4157 respectively as shown in fig.5 represent scatter plot for observed and simulated runoff for initial simulation. After performing number of trials, $\mathrm{R}^{2}$ and NSE values reached to desirable limits as shown in fig. 7 .

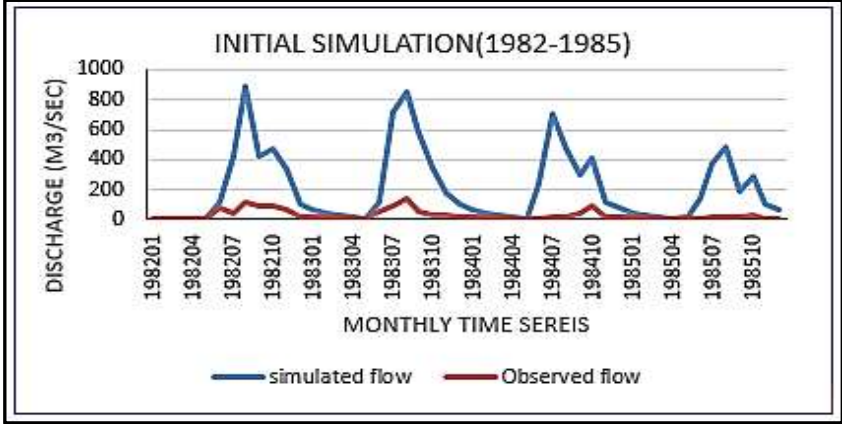

Chart-1: Average monthly observed and simulated runoff for the initial simulation

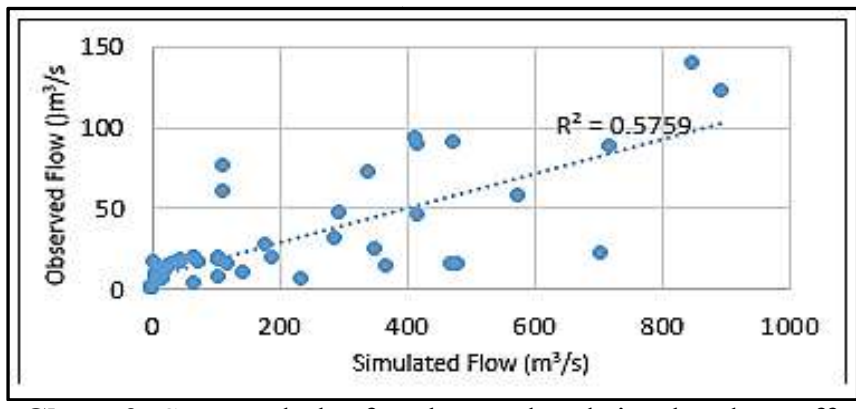

Chart-2: Scattered plot for observed and simulated runoff for initial simulation

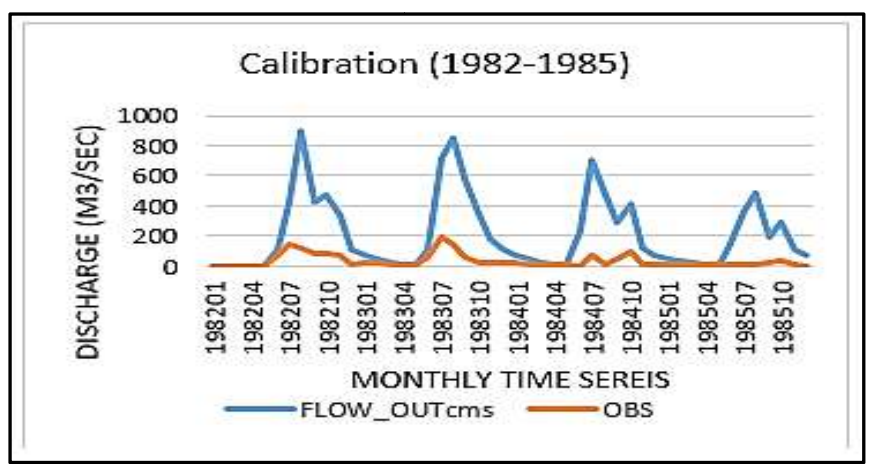

Chart-3: Average monthly observed and simulated runoff for the period of calibration

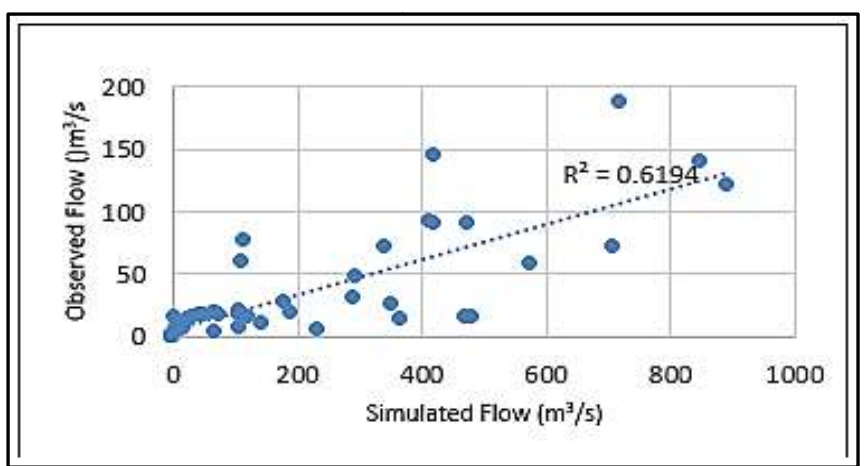

Chart-4: Scattered plot for observed and simulated runoff for calibration period

\section{CONCLUSION}

Many hydrological models have been used for the sediment yield analysis among those, SWAT is a widely used model to determine the watershed components. The present study adopted the hydrological model SWAT for the Runoff 
assessment for the Malaprabha sub-basin. The model behaved well for the calibration and validation periods for runoff. Model performed fine for the calibration validation of runoff which were found within the range of acceptance. It can be concluded that model performs good for the runoff evaluation.

\section{REFERENCES}

[1] Nagraj S. Patil, Rajkumar V. Raikar and Manoj S. "Runoff Modelling for Bhima River using Swat Hydrological Model". International Journal of Engineering Research \& Technology (IJERT) ISSN: 2278-0181,Vol. 3 Issue 7, July - 2014.

[2] VikashShivhare, M K Goel, C K Singh. "Simulation Of Surface Runoff For Upper TapiSubcatchment Area (Burhanpur Watershed) Using Swat". The International Archives of the Photogrammetry, Remote Sensing and Spatial Information Sciences, Volume XL-8, 2014. ISPRS Technical Commission VIII Symposium, 09 12 December 2014, Hyderabad, India.

[3] Sanjay K. Jain, JaivirTyagi, Vishal Singh "Simulation of Runoff and Sediment Yield for a Himalayan Watershed Using SWAT Model". J. Water Resource and Protection, 2010, Vol. 2, pp 267-281.

[4] J. G. Arnold, D. N. Moriasi, P. W. Gassman, K. C. Abbaspour, M. White, R. Srinivasan, C. Santhi, R. D. Harmel, A. van Griensven, M. W. Van Liew, N. Kannan, M. K. Jha (2012) "SWAT: Model use, calibration, and validation" American Society of Agricultural and Biological Engineers ISSN 21510032 .

[5] Neitsch, S. L., Arnold, J. G., Kiniry, J. R. and Williams, J. R. (2011). Soil and Water Assessment Tool Theoretical Documentation, Version 2009. Temple, Tex.: Texas Water Resources Institute Technical Report No. 406.

[6] Z. M. Easton, D. R. Fuka, E. D. White, A. S. Collick, B. BirukAshagre, M. McCartney, S. B. Awulachew, A. A. Ahmed, and T. S. Steenhuis. "A multi basin SWAT model analysis of runoff and sedimentation in the Blue Nile, Ethiopia". Hydrol. Earth Syst. Sci., 14, 18271841, 2010.

[7] V. Garg, I. Chaubey, B. E. Haggard "Impact of Calibration Watershed on Runoff Model Accuracy". Soil \& Water Division of ASAE June 2003. 